\title{
Regulation of the expression of a pelA::uidA fusion in Erwinia chrysanthemi and demonstration of the synergistic action of plant extract with polygalacturonate on pectate lyase synthesis
}

\author{
Claude Bourson, ${ }^{1}$ Sylvie Favey, ${ }^{2}$ Sylvie Reverchon ${ }^{*}$ and Janine Robert-Baudouy ${ }^{1}$ \\ 'INSA 406 Laboratoire Génétique Moléculaire des Microorganismes (LGMM), 20 av. Albert Einstein. \\ 69621 Villeurbanne cedex, France \\ ${ }^{2}$ INRA INA P-G, Laboratoire de pathologie végétale, 16 rue Claude Bernard, 75231 Paris cedex 05, France
}

(Received 21 April 1992; revised 25 August 1992; accepted 1 September 1992)

\begin{abstract}
The phytopathogenicity of Erwinia chrysanthemi is chiefly supported by the production of pectate lyase isoenzymes, encoded by the pel genes. One of these enzymes, PelA, encoded by the pelA gene, seems to represent only a small part of the total pectate lyase activity, but is required for full bacterial pathogenicity. To study the regulation of pelA gene expression, a pelA :: uidA gene fusion was constructed. Expression of this fusion was analysed under various growth conditions and in various genetic backgrounds. Whatever the culture conditions, the pelA gene was weakly expressed. Moreover, pelA expression seems not to be regulated by the pecS gene product, but essentially by the $\boldsymbol{k d g} \boldsymbol{R}$ gene product. In many plant-associated bacteria, genes involved in pathogenicity are induced by certain plant compounds. In this work, we demonstrate that $E$. chrysanthemi pel genes are induced in the presence of plant extracts, but only in synergy with known pectate lyase inducers (KDG: 2-keto-3deoxygluconate; DKII: 2,5-diketo-3-deoxygluconate). However, different pel genes did not exhibit the same sensitivity to plant signal molecules. Partial purification of inducing plant compounds suggested that plant extracts contain at least one molecule involved in pectate lyase induction. This compound is thermoresistant, and has a low molecular mass and a very hydrophilic behaviour.
\end{abstract}

\section{Introduction}

Erwinia chrysanthemi is a phytopathogenic bacterium causing soft-rot disease on many plant species. Its pathogenesis is supported by the production and secretion of a battery of depolymerizing enzymes such as pectinases, cellulases and proteases (Collmer \& Keen, 1986). Pectin is a major component of plant cell wall material and its degradation leads to maceration of plant tissues. E. chrysanthemi strain 3937 produces and secretes one pectin methylesterase and five pectate lyase (Pel) isoenzymes, named PelA to PelE, with isoelectric points ranging from 4.5 to $9 \cdot 2$ (Bertheau et al., 1984). These enzymes are secreted into the external medium, where they cleave pectin to generate unsaturated digalacturonate. This degradation product enters the bacterial cell where it is further degraded through a complex enzymic pathway (Fig. 1). The five different pel genes, organized

* Author for correspondence. Tel. (33) 72438088 ; fax (33) 7243 8511

Abbreviations: DKII, 2,5-diketo-3-deoxygluconate; KDG, 2-keto-3deoxygluconate; PGA, polygalacturonate. into two clusters, encode the five pectate lyase isoenzymes (Hugouvieux-Cotte-Pattat et al., 1989; Kotoujansky ' $t$ al., 1985; Reverchon et al., 1985). One cluster contains the pelB and pelC genes which encode the neutral isoenzymes (PelB and PelC); the other cluster contains pelA, pelD and pelE genes which encode the acidic isoenzyme (PelA) and the basic isoenzymes (PelD and PelE).

All the genes involved in pectin degradation, including these five pectate lyase genes, constitute independent transcriptional units. Expression of these genes is induced in the presence of polygalacturonate (PGA) or galacturonate. The true intracellular inducers, 2-keto-3deoxygluconate (KDG) and 2,5-diketo-3-deoxygluconate (DKII), are catabolic products of galacturonate or PGA (Fig. 1) (Chatterjee et al., 1985; Collmer \& Bateman, 1981; Condemine et al., 1986; HugouvieuxCotte-Pattat \& Robert-Baudouy, 1987). Inducibility by these pectic derivatives is mediated by the product of $k d g R$, a negative regulatory gene (Condemine \& RobertBaudouy, 1987; Reverchon et al., 1991). $k d g R$ seems to be the only regulatory gene controlling expression of genes coding for the intracellular steps of the pectin 


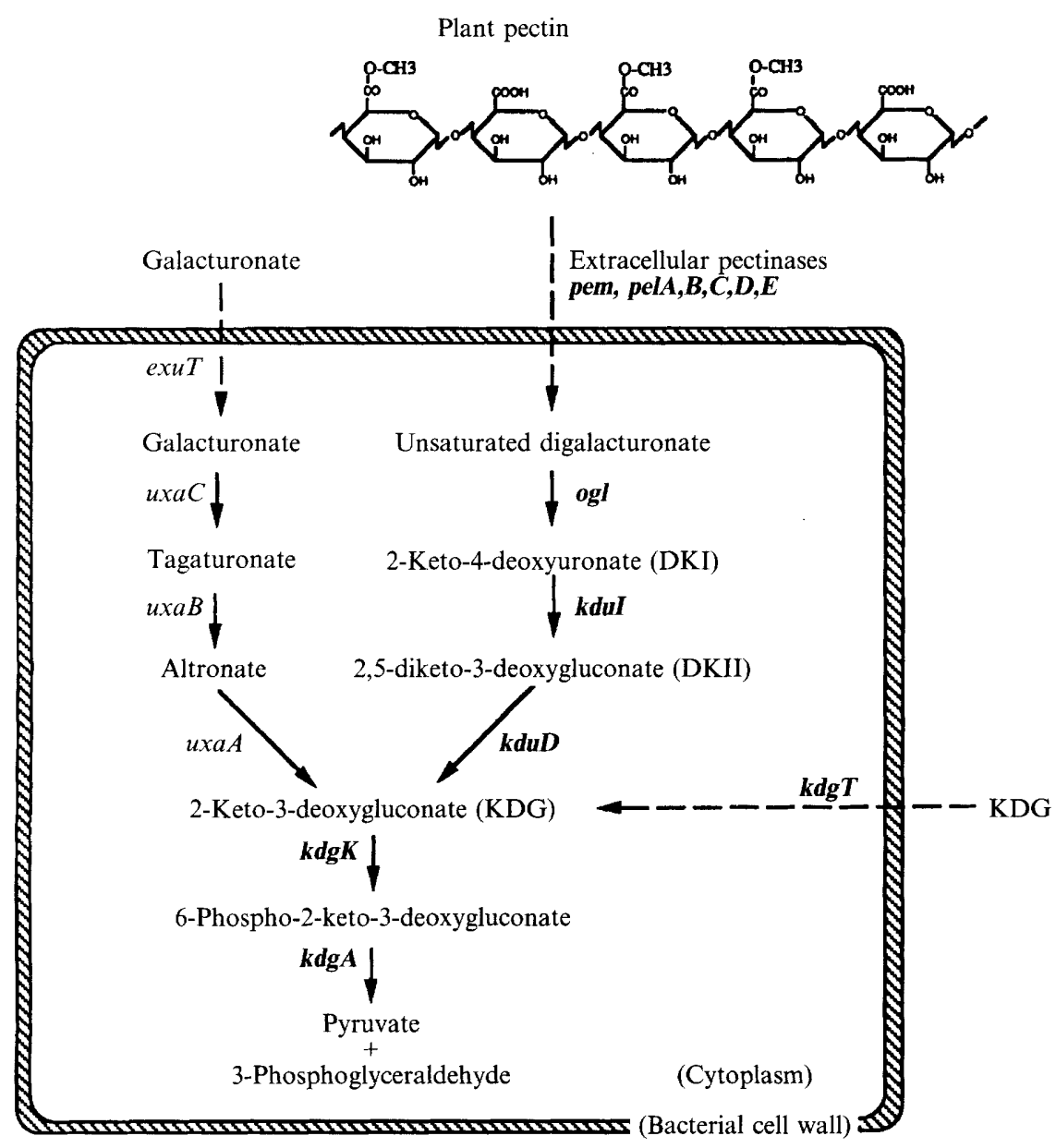

Fig. 1. Degradative pathway of pectin and galacturonate in $E$. chrysanthemi. The different steps are catalysed by the products of the genes specified near the corresponding arrow: pem, gene coding pectin methylesterase; pel, pectate lyase (actually five genes: pelA to pelE); ogl, oligogalacturonate lyase; $k d u I$, 5-keto-4-deoxyuronate isomerase; $k d u D$, 2-keto-3-deoxygluconate oxidoreductase; $u x a C$, uronate isomerase; $u x a B$, altronate oxidoreductase; $u x a A$, altronate hydrolase; $k d g K, 2-$ keto-3-deoxygluconate kinase; $k d g A, 2$-keto-3deoxy-6-phosphogluconate aldolase. The transport systems mediating the entry of galacturonate and 2-keto-3-deoxygluconate into the cell are also indicated (exuT and $k d g T$. respectively).

(External medium)

degradative pathway. In contrast, synthesis of pectin methylesterase and pectate lyase is under the control of many other regulatory genes (Condemine \& RobertBaudouy, 1987; Hugouvieux-Cotte-Pattat et al., 1986; Hugouvieux-Cotte-Pattat \& Robert-Baudouy, 1989; Reverchon et al., 1990). Recently, one of them, pecS, has been characterized, and seems to negatively control pel gene expression only (Reverchon et al., 1990).

Pathogenicity tests performed on Saintpaulia plants in vitro suggest that the genes of the pelBC cluster are not essential for bacterial pathogenicity (Boccara et al., 1988). In contrast, each of the enzymes produced by the pelADE gene cluster is required for pathogenicity (Boccara et al., 1988). The two alkaline pectate lyases PelE and PelD, which correspond to approximately $60 \%$ and $15 \%$ of total pectate lyase activity, respectively, exhibited strong plant tissue macerating activity. The unique acidic pectate lyase PelA of E. chrysanthemi represents $3 \%$ of total pectate lyase activity and shows a slight maceration ability (Barras et al., 1987; Garibaldi \& Bateman, 1971; Tamaki et ál., 1988). However, pathogenicity of $E$. chrysanthemi pelA mutants is strongly decreased. Regarding the weak contribution of PelA to total Pel activity and its crucial importance in $E$. chrysanthemi pathogenicity, we wondered whether weak PelA activity is related to weak transcription of the pelA gene and if the PelA protein could have another major enzymic activity. This led us to construct a pel:: uidA fusion and to follow its expression in various growth conditions and in many genetic backgrounds.

The interaction between plant and pathogen is a dynamic process involving signal exchange between interacting organisms. Indeed, for most plant-associated bacteria it has been shown that many bacterial genes involved in plant-bacteria interaction are induced by plant molecules. For example, the expression of the Agrobacterium vir genes that govern virulence is induced by acetosyringone and other plant phenolic compounds (Bolton et al., 1986; Stachel et al., 1985, 1986). The nod genes of Rhizobium species, which control nodulation mechanisms, are induced by some plant compounds identified as flavonoids (Downie \& Johnston, 1988; Redmond et al., 1986). Consequently, we investigated the effect of plant compounds such as acetosyringone, 
Table 1. Bacterial strains, plasmids and phages

\begin{tabular}{|c|c|c|}
\hline Strain & Genotype/description* & Source/reference \\
\hline $\begin{array}{l}\text { Erwinia chrysanthemi } \\
\text { A350 }\end{array}$ & $\operatorname{lm} r T^{c}$ lac $Z$; used as wild-type strain & $\begin{array}{l}\text { Hugouvieux-Cotte-Pattat \& } \\
\text { Robert-Baudouy (1985) }\end{array}$ \\
\hline $\begin{array}{l}\text { A1696 } \\
\text { A1702 }\end{array}$ & $\begin{array}{l}\operatorname{lm} r T^{c} \text { lacZ pelA:: uidA(kan) } \\
\operatorname{lm} r T^{c} \text { lac } Z \text { pelA : uidA(kan) arg ool }\end{array}$ & \\
\hline A1688 & $\operatorname{lmr} T^{c}$ lac $Z$ pelA::uidA(kan) arg $k d g K$ & \\
\hline A 1698 & $\operatorname{lmr} T^{e}$ lacZ pelA ::uidA(kan) kduD::Mu(Ap,lac) & This work \\
\hline A1697 & $l m r T^{c}$ lac $Z$ pelA :: uidA(kan) $k d g R$ & \\
\hline A1699 & $\operatorname{lmr} T^{c}$ lacZ pelA ::uidA(kan) pecS::Mu(Cm) & \\
\hline A1 808 & $\operatorname{lmr} T^{c}$ lacZ pelB:: uidA(kan) & \\
\hline A1812 & $\operatorname{lmr} T^{c}$ lac Z pelC $:: \operatorname{uid} A(\mathrm{kan})$ & N. Hugouvieux-Cotte-Pattat \\
\hline A1813 & $\operatorname{lmr} T^{c}$ lac Z pelD ::uidA(kan) & and others (unpublished) \\
\hline A 1828 & $\operatorname{lm} r T^{c}$ lac Z pelE:: uidA(kan) & \\
\hline $\begin{array}{l}\text { Escherichia coli } \\
\text { NM522 }\end{array}$ & $\Delta($ lac-pro $A B)$ thi hsd5 supE $\mathrm{F}^{\prime}\left(\right.$ pro $A B^{+}$, lacI $I^{q}$, lac $\left.Z \Delta \mathrm{M} 15\right)$ & Stratagene \\
\hline Phages & & \\
\hline PhiEC2 & General transducing phage of $E$. chrysanthemi & Resibois et al. (1984) \\
\hline \multicolumn{3}{|l|}{ Plasmids } \\
\hline pBluescript & Ap, 'lacZ & Stratagene \\
\hline pBR325 & $\mathrm{Ap}, \mathrm{Tc}, \mathrm{Cm}$ & Bolivar (1978) \\
\hline p19014 & Plasmid harbouring insertional uidA(kan) cassette & N. Bardonnet (unpublished) \\
\hline pBLI625 & pBluescript derivative harbouring pelE and pelA genes & This work \\
\hline pBRSE5 & $\begin{array}{l}\text { pBR } 325 \text { derivative harbouring downstream region and } \\
\text { first codons of pelA gene }\end{array}$ & This work \\
\hline pAUID5 & pBR325 derivative harbouring pelA::uidA(kan) fusion & This work \\
\hline
\end{tabular}

* Genotype symbols are according to Bachmann (1990). $\operatorname{lmr} T^{c}$ indicates that the transport system encoded by the $\operatorname{lm} T$ gene, which mediates entry of lactose, melibiose and raffinose into the cells, is constitutively expressed.

and of crude plant extracts, on the expression of pel genes and especially on the pelA gene.

\section{Methods}

Bacterial strains, plasmids and culture conditions. Bacterial strains and plasmids used in this study are shown in Table 1. Cells were grown in complete rich LB medium or in synthetic M63 medium (Miller, 1972). When required, media were supplemented with glycerol $\left(2 \mathrm{~g} \mathrm{l}^{-1}\right)$ as carbon source, amino acids $\left(40 \mathrm{mg} \mathrm{l}^{-1}\right)$, and with antibiotics at the following concentrations: kanamycin, $20 \mu \mathrm{g} \mathrm{ml}^{-1}$; ampicillin, $50 \mu \mathrm{g}$ $\mathrm{ml}^{-1}$; tetracycline, $10 \mu \mathrm{g} \mathrm{ml}^{-1}$; chloramphenicol, $20 \mu \mathrm{g} \mathrm{ml}^{-1}$. Media were solidified with Difco agar $\left(15 \mathrm{~g}^{-1}\right)$. Polygalacturonate $(0.25 \%$, $\mathrm{w} / \mathrm{v})$ was added to culture media as a pectate lyase inducer.

Enzyme assays. Pectate lyase and $\beta$-glucuronidase assays were performed on toluenized extracts of cells grown to the late exponential growth phase. To avoid catabolic repression of pectate lyase synthesis, cultures were grown in M63 minimal medium supplemented with glycerol as carbon source. Pectate lyase activity was determined by measuring the degradation of polygalacturonate into unsaturated products that absorb at $235 \mathrm{~nm}$ (Moran et al., 1968); specific activity was expressed in $\mu \mathrm{mol}$ unsaturated products liberated $\mathrm{min}^{-1}$ (mg bacterial dry weight $)^{-1}$. $\beta$-Glucuronidase activity was assayed by using $p$-nitrophenyl $\beta$-D-glucuronide as substrate (Novel et al., 1974). The degradation product, $p$-nitrophenol, was detected at $405 \mathrm{~nm}$ $(\varepsilon=0.0045) . \beta$-Glucuronidase specific activity was expressed in $\mathrm{nmol}$ $p$-nitrophenol liberated $\min ^{-1}(\mathrm{mg} \text { bacterial dry weight })^{-1}$.

Genetic techniques and DNA methods. Transduction with phage phiEC2 was performed according to Resibois et al. (1984). Markerexchange recombinations were obtained after successive cycles of growth in a low-phosphate medium (Roeder \& Collmer. 1985), supplemented for the first culture with $1 \%(\mathrm{v} / \mathrm{v})$ plant extract. Standard molecular cloning techniques used in this study (small- and large-scale plasmid DNA extraction, restriction enzyme digestion. agarose gel electrophoresis, DNA ligation, transformation and electroporation of bacterial cells) were performed as described by Ausubel et al. (1987) and Sambrook et al. (1989).

The uidA-kan cassette was provided by N. Bardonnet (unpublished results). The uidA gene was isolated from Escherichia coli and codes for $\beta$-glucuronidase activity, which is easy to detect and to assay. This gene was deleted of its own promoter and cloned in an insertional cassette including kanamycin resistance ( $k a n)$ as marker gene.

Plant extract preparation and partial purification of inducing factors. Crude plant extracts were obtained by crushing plant organs (leaves and stems of Diffenbachia, fruit of pumpkin, or carrot roots). The resulting juices were clarified by centrifugation and subsequent filtrations on membranes of decreasing porosity. Extracts were sterilized by final filtration on a $0.22 \mu \mathrm{m}$ porosity membrane and stored in aliquots for several months at $-20^{\circ} \mathrm{C}$.

For partial purification, plant extracts were first filtered on a Centrikon 10 device (Amicon) which eliminates molecules of molecular mass higher than $10 \mathrm{kDa}$. The filtered solution was fractionated on a Fractogel column with a $5 \mathrm{kDa}$ threshold (TSK 40, Merck). Elution was done with $20 \mathrm{mM}-\mathrm{NH}_{4} \mathrm{OH}$ and all the fractions were tested for their inducing properties. Inducing fractions of different runs were pooled, concentrated in a vacuum dryer and subsequently fractionated on HPLC columns. The first column used was an $\mathrm{NH}_{2}$ type (Spherisorb 55 $\mathrm{NH}_{2}$ ) and elution was performed with an acetonitrile $/ \mathrm{H}_{2} \mathrm{O}$ gradient. As below, each fraction was tested and inducing ones were pooled and concentrated. The pool of inducing fractions was finally loaded on a hydrophobic interaction column (C18 type: Lichosorb L10 C18 25R) and eluted with an acetonitrile/acetic acid $/ \mathrm{H}_{2} \mathrm{O}$ gradient. Each fraction 
was tested for its inducing property. Inducing fractions of different runs were pooled and concentrated for characterization.

\section{Results}

Construction of the E. chrysanthemi mutant containing the pelA::uidA fusion

The transcriptional pelA::uidA fusion was constructed by insertion of a uidA-kan cassette into the open reading frame of the pel.4 gene (Fig. 2). Since the uidA promoter was deleted, expression of this reporter gene is dependent on pel $A$ regulatory elements.

The $4.5 \mathrm{~kb} H$ indIII-PvuII fragment, harbouring the E. chrysanthemi pelA and pelE genes, was cloned in the HindIII-SmaI sites of pBluescript $\mathrm{KS}+$, to produce pBLI625. Then the $2 \mathrm{~kb} E c o$ RI fragment harbouring the regulatory region and the beginning of the coding region of pelA was subcloned from pBLI625 into the EcoRI site of pBR325, giving pBRSE5. A uidA-kan cassette, obtained by SmaI digestion of p19014, was introduced into the unique HpaI site of pBRSE5. The resulting plasmid pAUID5, containing the pelA:: uidA fusion, was introduced into $E$. chrysanthemi strain A350 by electroporation. Recombination of the pelA::uidA fusion in the chromosome was performed by successive cultures in low-phosphate medium. We obtained 10 recombinants with the correct antibiotic resistance pattern: kanamycin resistance (kan is the fusion marker), ampicillin and tetracycline sensitivity (segregation of the pBR325 derivative replicon). The Pel pattern of these recombinants was then analysed by isoelectric focusing. Seven of the 10 recombinants had lost PelA isoenzyme activity and corresponded to pelA mutants (Fig. 3) A Southern hybridization experiment confirmed that the $\operatorname{pel} A:$ uid $A$ fusion was correctly recombined in these seven mutants (data not shown).

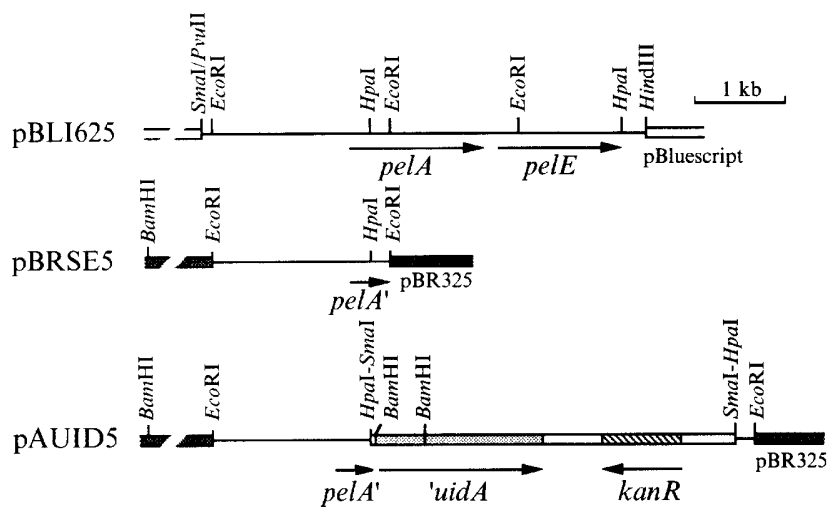

Fig. 2. Construction of pelA::uidA fusions. The successive plasmids for the construction of the fusion are represented in a linear form. The derived vector is indicated on the right-hand side of the plasmid; arrows represent gene extent and transcription direction.
Expression of the pelA::uidA fusion in various growth conditions

The pelA::uidA mutant A1696 was analysed for $\beta$ glucuronidase synthesis in the absence and presence of PGA as inducer and also in the presence of plant extract to test possible induction by plant molecules (Table 2). Pectate lyase residual activity corresponding to the global activities of PelB, PelC, PelD and PelE was also determined in the same growth conditions (Table 2). The pelA::uidA fusion was poorly expressed in all conditions tested. A very weak induction was observed with PGA. A better induction could be detected in the presence of both PGA and plant extract (Table 2). Therefore it seems that the weak contribution of PelA to the total Pel activity is really related to weak transcription of $p e l A$ and is probably not due to another major enzymic activity of the PelA protein. Moreover, Pel residual activity is not affected by the lack of the pelA gene product, confirming that PelA activity contributes a very small part of the total Pel activity in all conditions tested.

pelA:: uidA expression in different genetic backgrounds

By using the transducing phage phiEC2, the pelA:: uidA fusion was transduced into different mutants of the pectinolytic pathway: ogl, $k d u D$ and $k d g K$. Transductants were checked for their antibiotic resistance pattern and the loss of PelA activity on an electrofocusing gel. $\beta$-Glucuronidase was assayed on cultures grown without inducers, with PGA and with PGA supplemented with plant extract (Table 3).

In the presence of PGA, an ogl mutant accumulates digalacturonates and is unable to produce true $\mathrm{Pel}$ inducers (KDG and DKII) (Chatterjee et al., 1985; Reverchon \& Robert-Baudouy, 1987a). In the ogl mutant, the pelA fusion was not induced by PGA or PGA plus plant extract (Table 3), indicating that pelA induction also requires the degradation of digalacturonate.

In $k d u D$ or $k d g K$ mutants, addition of PGA to the culture medium resulted in a significant induction of pelA expression (Table 3), suggesting that pelA induction is also sensitive to the DKII and KDG accumulation that occurs in these mutants (Chatterjee et al.. 1985; Condemine et al., 1986; Hugouvieux-Cotte-Pattat \& Robert-Baudouy, 1987).

The pel::uidA fusion was also transduced into $k d g R$ and pec $S$ regulatory mutants. The $k d g R$ gene product regulates all the pectinolytic pathway genes (Hugouvieux-Cotte-Pattat \& Robert-Baudouy, 1989; Reverchon \& Robert-Baudouy, 1987b), and pecS is another negative regulatory gene with a narrow range, since it controls only pel gene expression and has no action on the intracellular steps of pectinolysis 

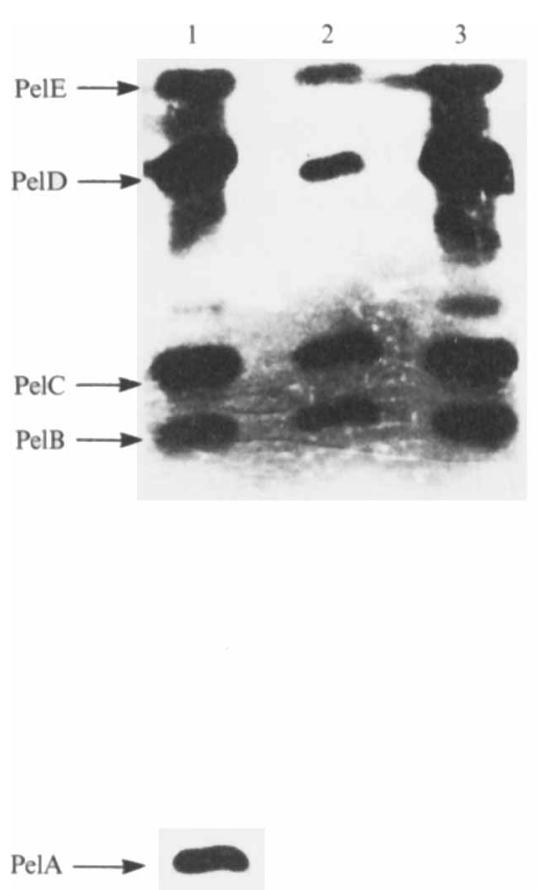

Fig. 3. Isoelectric focusing of pectate lyase enzymes present in culture supernatant of different strains. 1, Supernatant of strain A350 (wildtype) cultivated in the presence of PGA. 2 and 3, supernatant of strain A1696 (pelA :: uidA) cultivated in the absence and presence of PGA, respectively.

Table 2. Expression of a pelA:: uidA fusion in various growth conditions

Bacteria were grown in M63 minimal medium with glycerol $(2 \mathrm{~g}$ $\mathrm{I}^{-1}$ ) as carbon source. PGA and plant extract were added at $0 \cdot 25 \%$ $(\mathrm{w} / \mathrm{v})$ and $1 \%(\mathrm{v} / \mathrm{v})$, respectively. Pectate lyase activity is expressed in $\mu \mathrm{mol}$ unsaturated product liberated $\mathrm{min}^{-1}$ ( $\mathrm{mg}$ bacterial dry weight $)^{-1}$. $\beta$-Glucuronidase activity is expressed in nmol $p$ nitrophenol liberated $\mathrm{min}^{-1}$ (mg bacterial dry weight $)^{-1}$. ND, Not detectable.

\begin{tabular}{llcc}
\hline \hline & & $\begin{array}{c}\text { Pectate } \\
\text { lyase } \\
\text { activity }\end{array}$ & $\begin{array}{c}\beta \text {-Glucuronidase } \\
\text { activity }\end{array}$ \\
\hline A1696 & Inducer & $0 \cdot 01$ & 2 \\
(pel:: uidA) & PGA & 0.07 & 5 \\
& PGA + carrot extract & $2 \cdot 22$ & 7 \\
A350 & None & $0 \cdot 01$ & ND \\
(wild-type) & Carrot extract & 0.02 & ND \\
& PGA & 0.09 & ND \\
& PGA + carrot extract & $2 \cdot 29$ & ND \\
& Galacturonate (GalA) & $0 \cdot 16$ & ND \\
& GalA + carrot extract & $1 \cdot 18$ & ND \\
\hline \hline
\end{tabular}

(Reverchon et al., 1990). In a $k d g R$ mutant, pelA showed the same constitutive expression whatever the culture conditions (Table 3). The level of pelA expression was nearly equivalent to the maximum induced level observed
Table 3. Expression of a pelA:: uidA fusion in various genetic backgrounds

Bacteria were grown in M63 minimal medium with glycerol (2 g $\mathrm{I}^{-1}$ ) as carbon source. PGA and plant extract were added at $0.25 \%$ $(\mathrm{w} / \mathrm{v})$ and $1 \%(\mathrm{v} / \mathrm{v})$, respectively. See Table 2 for units of enzyme activity.

\begin{tabular}{|c|c|c|c|}
\hline Strain & Inducer & $\begin{array}{l}\text { Pectate } \\
\text { lyase } \\
\text { activity }\end{array}$ & $\begin{array}{c}\beta \text {-Glucuronidase } \\
\text { activity }\end{array}$ \\
\hline $\begin{array}{l}\mathrm{A} 1696 \\
(\text { pelA : : uidA })\end{array}$ & $\begin{array}{l}\text { None } \\
\text { PGA } \\
\text { PGA + carrot } \\
\text { extract }\end{array}$ & $\begin{array}{l}0.01 \\
0.07 \\
2 \cdot 22\end{array}$ & $\begin{array}{l}2 \\
5 \\
7\end{array}$ \\
\hline $\begin{array}{l}\mathrm{A} 1702 \\
\quad(\text { pelA }:: \text { uidA }, \text { ogl })\end{array}$ & $\begin{array}{l}\text { None } \\
\text { PGA } \\
\text { PGA + carrot } \\
\text { extract }\end{array}$ & $\begin{array}{l}0 \cdot 02 \\
0 \cdot 04 \\
0 \cdot 14\end{array}$ & $\begin{array}{l}3 \\
3 \\
3\end{array}$ \\
\hline $\begin{array}{l}\mathrm{A} 1698 \\
(\text { pelA }:: \text { uid } A, k d u D)\end{array}$ & $\begin{array}{l}\text { None } \\
\text { PGA } \\
\text { PGA + carrot } \\
\text { extract }\end{array}$ & $\begin{array}{r}0.02 \\
13 \cdot 50 \\
8 \cdot 31\end{array}$ & $\begin{array}{r}3 \\
22 \\
14\end{array}$ \\
\hline $\begin{array}{l}\mathrm{A} 1688 \\
\quad(p e l A:: \text { uid } A, k d g K)\end{array}$ & $\begin{array}{l}\text { None } \\
\text { PGA } \\
\text { PGA + carrot } \\
\text { extract }\end{array}$ & $\begin{array}{r}0.02 \\
16.90 \\
21.90\end{array}$ & $\begin{array}{r}3 \\
20 \\
13\end{array}$ \\
\hline $\begin{array}{l}\mathrm{A} 1697 \\
\quad(\text { pelA }:: \text { uid } A, k d g R)\end{array}$ & $\begin{array}{l}\text { None } \\
\text { PGA } \\
\text { PGA + carrot } \\
\text { extract }\end{array}$ & $\begin{array}{l}0 \cdot 46 \\
0.94 \\
2 \cdot 72\end{array}$ & $\begin{array}{l}27 \\
27 \\
19\end{array}$ \\
\hline $\begin{array}{l}\mathrm{A} 1699 \\
\quad(p e l A:: \text { uid } A, \operatorname{pec} S)\end{array}$ & $\begin{array}{l}\text { None } \\
\text { PGA } \\
\text { PGA + carrot } \\
\text { extract }\end{array}$ & $\begin{array}{l}0 \cdot 24 \\
1 \cdot 20 \\
6 \cdot 33\end{array}$ & $\begin{array}{l}5 \\
6 \\
4\end{array}$ \\
\hline
\end{tabular}

Table 4. Influence of plant extract concentration on Pel synthesis

Bacteria were grown in M63 minimal medium with glycerol (2 $\mathrm{g}$ $\left.1^{-1}\right)$ as carbon source. PGA was added at $0.25 \%(\mathrm{w} / \mathrm{v})$, and carrot extract was added as specified. See Table 2 for units of pectate lyase activity.

\begin{tabular}{ccc}
\hline \hline $\begin{array}{c}\text { Plant extract } \\
(\%, v / v)\end{array}$ & $\begin{array}{c}\text { Pectate lyase } \\
\text { activity }\end{array}$ & Induction ratio \\
\hline None & 0.09 & \\
0.2 & 0.13 & $1 \cdot 4$ \\
1.0 & $2 \cdot 03$ & $22 \cdot 5$ \\
2.0 & $1 \cdot 83$ & $20 \cdot 3$ \\
$4 \cdot 0$ & 1.80 & $20 \cdot 0$ \\
8.0 & 1.90 & $21 \cdot 1$ \\
$12 \cdot 0$ & 1.28 & $14 \cdot 2$ \\
\hline
\end{tabular}

in $k d g K$ or $k d u D$ mutants. These results suggest that the $k d g R$ gene product is the major regulatory protein responsible for pelA repression in absence of inducer. The pelA::uidA fusion had approximately the same expression in a pec $S$ mutant as in the wild-type strain (Table 3). This suggests that pecS has no significant effect on pelA expression. In contrast with the other pel genes, 
Table 5. Effect of plant extract on the expression of the different pel::uidA fusions

Bacteria were grown in M63 minimal medium with glycerol $(2 \mathrm{~g}$ $\left.1^{-1}\right)$ as carbon source. PGA and plant extract were added at $0.25 \%$ $(\mathrm{w} / \mathrm{v})$ and $1 \%(\mathrm{v} / \mathrm{v})$, respectively. See Table 2 for units of enzyme activity.

\begin{tabular}{|c|c|c|c|c|}
\hline Strain & Inducer & $\begin{array}{l}\text { Pectate } \\
\text { lyase } \\
\text { activity }\end{array}$ & $\begin{array}{c}\beta \text {-Glucuronidase } \\
\text { activity }\end{array}$ & $\begin{array}{c}\text { Induction } \\
\text { ratio }\end{array}$ \\
\hline $\begin{array}{l}\mathrm{A} 1696 \\
\quad(\text { pelA }:: \text { uidA })\end{array}$ & $\begin{array}{l}\text { None } \\
\text { PGA } \\
\text { PGA + carrot } \\
\text { extract }\end{array}$ & $\begin{array}{l}0 \cdot 01 \\
0 \cdot 07 \\
2 \cdot 22\end{array}$ & $\begin{array}{l}2 \\
5 \\
7\end{array}$ & $3 \cdot 5$ \\
\hline $\begin{array}{l}\mathrm{A} 1808 \\
(\text { pelB }:: \text { uid } A)\end{array}$ & $\begin{array}{l}\text { None } \\
\text { PGA } \\
\text { PGA + carrot } \\
\text { extract }\end{array}$ & $\begin{array}{l}0.01 \\
0.04 \\
2 \cdot 49\end{array}$ & $\begin{array}{r}22 \\
37 \\
167\end{array}$ & $7 \cdot 5$ \\
\hline $\begin{array}{l}\mathrm{A} 1812 \\
(\text { pelC }:: \text { uidA })\end{array}$ & $\begin{array}{l}\text { None } \\
\text { PGA } \\
\text { PGA + carrot } \\
\text { extract }\end{array}$ & $\begin{array}{l}0 \cdot 10 \\
0 \cdot 14 \\
2 \cdot 71\end{array}$ & $\begin{array}{r}15 \\
25 \\
284\end{array}$ & $18 \cdot 9$ \\
\hline $\begin{array}{l}\mathrm{A} 1813 \\
\quad(\text { pelD }:: \text { uidA })\end{array}$ & $\begin{array}{l}\text { None } \\
\text { PGA } \\
\text { PGA + carrot } \\
\text { extract }\end{array}$ & $\begin{array}{l}0.02 \\
0.03 \\
0.89\end{array}$ & $\begin{array}{r}25 \\
37 \\
1560\end{array}$ & $62 \cdot 5$ \\
\hline $\begin{array}{l}\mathrm{A} 1828 \\
\quad(\text { pelE }:: \text { uid })\end{array}$ & $\begin{array}{l}\text { None } \\
\text { PGA } \\
\text { PGA + carrot } \\
\text { extract }\end{array}$ & $\begin{array}{l}0.01 \\
0.05 \\
0.46\end{array}$ & $\begin{array}{r}708 \\
672 \\
1260\end{array}$ & $1 \cdot 8$ \\
\hline
\end{tabular}

expression of pelA might not be regulated by pecS, confirming that $k d g R$ is the essential regulatory gene for pelA.

\section{Effect of plant extract on total Pel synthesis}

In the wild-type strain, PGA induced Pel synthesis only ninefold when added to culture medium (Table 2). Plant extract alone had no significant effect on Pel synthesis. However, the presence of both plant extract and PGA had a strong inducing effect on Pel synthesis: the induction ratio was about 230 -fold in the presence of $1 \%$ plant extract (Table 2). The same superinduction phenomenon was observed in the presence of galacturonate and plant extract (Table 2). Thus plant extract had a significant effect on Pel induction only in synergy with known pectic derivative inducers (KDG, DKII).

The effect of plant extract concentration on Pel synthesis was analysed in the presence of PGA. Induction ratios increased with the plant extract concentration to a maximum with $1 \%$ of plant extract (Table 4 ). With higher concentrations, the induction ratio decreased. This could be due to catabolite repression exerted by sugars present in the plant extract, or to the presence of $\mathrm{Pel}$ inhibitors in the extract. Extracts from Diffenbachia stems and leaves, pumpkin fruit and carrot roots gave similar inducing effects (data not shown), suggesting that the potential coinducing factor(s) is (are) widely distributed among plant species and tissues.

Effect of the plant extract in various genetic backgrounds

As shown above, the pelA gene product has only a very small effect on Pel global activity; for this reason Pel residual activity in the pelA mutant was equivalent to the Pel global activity in all the genetic backgrounds tested.

In an ogl mutant, PGA had no significant effect on Pel synthesis, and PGA with plant extracts showed only a very small inducing effect (Table 3 ). This induction was probably due to the presence in plant extract of small amounts of inducing compounds such as galacturonate.

When PGA was added to the culture medium of $k d u D$ or $k d g K$ mutants, accumulation of larger amounts of true inducers led to superinduction of Pel synthesis (Table 3). In these mutants, addition of plant extract had no significant effect on Pel synthesis, indicating that accumulation of true inducers in $k d u D$ or $k d g K$ mutants might lead to the full expression of pel genes which cannot be increased by plant extract.

In $k d g R$ and pecS mutants, high constitutive $\mathrm{Pel}$ expression was observed. However, Pel synthesis was still inducible by plant extract (Table 3 ).

\section{Effect of plant extract on the expression of the different pel::uidA fusions}

We compared the expression of the five pel genes by using uidA fusions with each pel gene. As for the pelA::uidA fusion, the same uidA-kan cassette was inserted into the open reading frame of each pel gene. The resulting constructions were introduced into the chromosome of $E$. chrysanthemi by homologous recombination. The $\beta$-glucuronidase activity corresponding to the expression of the pelA::uidA, pelB::uidA, pelC::uidA, pelD::uidA and pelE::uidA fusions was determined under various culture conditions, including the presence of plant extract (Table 5). Pel residual activity was also determined in these mutants to assess the contribution of the missing Pel isoenzyme (Table 5).

Expression of the pelD::uidA and pelE::uidA fusions in plant-extract-induced conditions was very high in comparison with other fusions. Consequently, Pel residual activity was significantly reduced in these mutants. Expression of the pelD::uidA fusion was strongly induced (62-fold) in the presence of plant extract. In contrast, the basal expression of the pelE:: uidA fusion was already high in non-induced conditions, and plant extract induced expression only $1 \cdot 8$-fold. Plant extract was also a poor inducer of pelA::uidA expression and had a fairly low effect on pelB::uidA and pelC::uidA expression. 


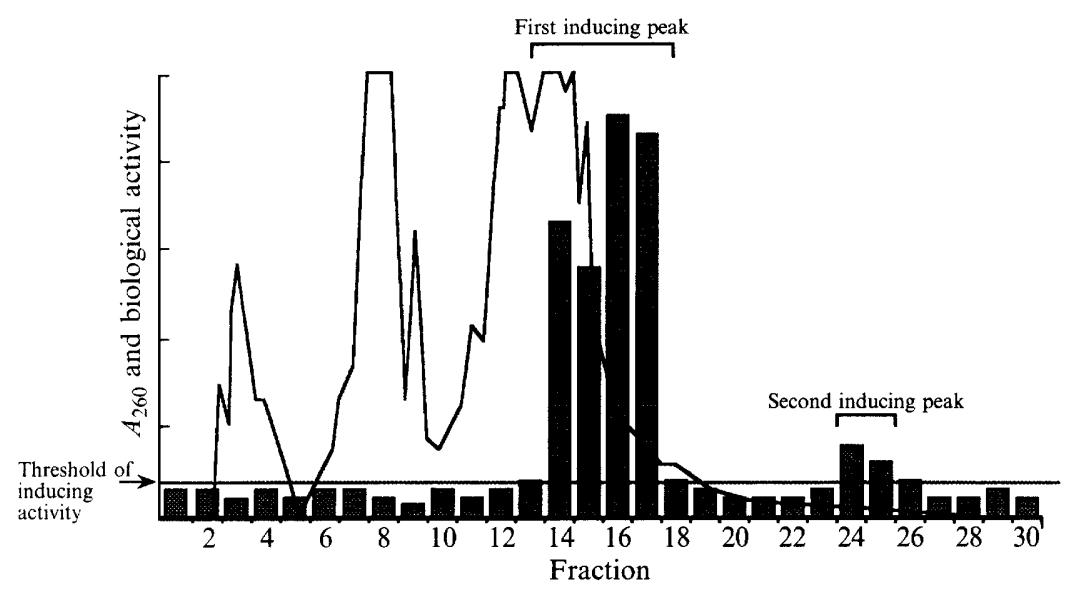

Fig. 4. Partial purification of plant inducing molecules. The elution profile $(-)$ and the inducing activity of the fractions ( ) are shown. The elution profile was obtained at $260 \mathrm{~nm}$; the total scale represents $0 \cdot 2$ optical density units. Fractions with a significant inducing activity were found in two peaks, indicated on the figure.

\section{Partial purification of plant extract inducing factors}

Plant phenolic compounds or flavonoids are known to induce expression of genes involved in plant-bacteria interaction, such as the vir genes in Agrobacterium (Bolton et al., 1986; Stachel et al., 1985, 1986) and the nod genes in Rhizobium (Downie \& Johnston, 1988; Redmond et al., 1986). To test if the inducing factor in plant extract was one of these compounds, some of these molecules (acetosyringone, coumarin, hydroxycoumarin, catecholamine and apigenin) were analysed in a wide range of concentrations (from $10^{-7} \mathrm{M}$ to $0.5 \mathrm{M}$ ) for their ability to induce or to enhance pel expression, in the presence or absence of PGA (data not shown). None of them showed an inducing or enhancing effect at any concentration, suggesting that the nature and structure of molecules inducing pel gene expression in E. chrysanthemi might be different from those of Agrobacterium or Rhizobium.

Combustion $\left(1 \mathrm{~h}\right.$ at $\left.800{ }^{\circ} \mathrm{C}\right)$ destroyed the inducing activity, indicating that the factor(s) is organic. The pelinducing factor of plant extract is thermoresistant since it could be autoclaved without loss of activity. As estimated by membrane filtration, the inducing factor is smaller than $10 \mathrm{kDa}$. During the first step of purification, which was a fractionation on an exclusion column, the inducing fractions were grouped in a unique wide peak, with an apparent molecular mass between 350 and $1000 \mathrm{Da}$. Therefore, the plant signal molecules have a relatively small molecular mass, and cannot be molecules such as PGA or pectins, nor proteins or large polymers.

A further step of purification was performed by HPLC on an $\mathrm{NH}_{2}$ column. Two distinct peaks of inducing compounds were obtained (Fig. 4). The major part of activity was in the first peak. This result suggested the presence in plant extract of either several inducing molecules, or only one compound which could exist in several distinct chemical or structural conformations. The two inducing peaks did not absorb significantly at
$260 \mathrm{~nm}$, confirming that the inducing factor(s) were not phenolic or flavonoid compounds.

Fractions of the first peak, which gave the stronger inducing effect, were pooled and subsequently fractionated on a hydrophobic interaction column (C18). Only the first fraction of the elution had inducing activity. This result demonstrated that the active molecule has a very hydrophilic behaviour. During concentration of the active fraction by vacuum, the inducing factor precipitated and we failed to redissolve it. However, the precipitate still had inducing activity, but it was impossible to characterize this compound by an analytical method such as NMR. Work is in progress in our laboratory to solubilize the active factor, to allow further purification and characterization of this molecule.

\section{Discussion}

The weak expression of the pelA::uidA fusion in all conditions tested indicates a low level of transcription. This result can be related to the presence of bad transcription signals in the pelA regulatory region (Favey et al., 1992). Analysis of pelA expression in mutants blocked in different steps of the pectin degradative pathway demonstrates that pelA induction, like the induction of other pel genes, requires the formation of DKII or KDG. Moreover, we demonstrated that pelA expression is regulated by the $k d g R$ gene product, as suggested by the presence of a typical KdgR-box in the pelA regulatory region (Favey et al., 1992). However, in contrast to the global Pel synthesis, the regulatory gene pecS did not seem to control pelA expression. Regarding weak pelA expression, it was impossible to explain the requirement of pelA for pathogenicity in terms of pectate lyase activity. These results allow Pel activity and pathogenicity to be distinguished. However, the requirement of pelA in pathogenicity could be related to a particular expression of that gene during the infection process. A gene, pec $X$, whose product seems to modulate 
pelA expression, has been detected in the region upstream of the pelA gene (Reverchon et al., 1986). Preliminary sequence data indicate that the pec $X$ product has some homology with a globin, and therefore could be involved in oxygen metabolism (S. Favay and others, unpublished results). These results suggest that PelA synthesis could be controlled by other factors, still unknown, such as oxygen concentration. The Agrobacterium virG gene has two promoters; one of them is inducible by a variety of environmental stresses (Mantis \& Winans, 1992; Winans, 1990). In the same way, pelA expression could be induced by various types of stress, such as oxygen limitation, which could act as important signals for the expression of E. chrysanthemi pathogenicity. The development of a disease caused by Erwinia strongly depends on the contamination levels but also on environmental conditions such as temperature, humidity and oxygen limitation (Perombelon, 1990). Therefore, it would be interesting to follow pelA expression during plant infection in different environmental conditions. To allow this investigation, we had to construct a merodiploid strain, to have an intact pelA gene required for infection, and a pelA ::uidA fusion as an activity marker.

We demonstrated that in $E$. chrysanthemi, Pel synthesis is strongly induced in the presence of both PGA and plant extract. The plant inducing effect is visible only in synergy with PGA or galacturonate, indicating that the plant inducing factor is not the natural true inducer like KDG or DKII. However, the presence of KDG or DKII seems to be required for effective action of plant extract of Pel synthesis. In an ogl mutant, which lacks the capacity to produce the natural true inducers from PGA, plant extract does not exhibit any inducing activity. In addition, in $k d g R$ and pecS regulatory mutants, Pel synthesis is still induced in the presence of plant extract, suggesting that induction by plant extract occurs through a mechanism other than $k d g R$ or pec $S$ derepression. To improve our knowledge of the relationship between plant-mediated induction and other forms of regulation, we are working on the construction of a double $k d g R$ pec $S$ mutant with which to investigate the effect of plant extract.

Plant extract does not have the same effect on the expression of the different pel genes. The expression of pelE and pelA seems to be poorly sensitive to plant extract induction. As previously discussed, pelA is probably sensitive to other environmental factors. A strong basal expression of pelE was observed, suggesting that the PelE isoenzyme is probably involved in the first steps of infection to allow pectin degradation and formation of inducers in order to initiate the expression of other pel genes. Expression of pelB and pelC is only moderately induced by plant extract, whereas pelD gene expression is very sensitive to plant inducing factor.
These observations could be correlated with the absence of evident roles of the PelB and PelC isoenzymes in pathogenicity and with the major contribution of the PelD isoenzyme during plant infection. We can suggest an ecological meaning for that induction mechanism. Pel synthesis is induced by PGA or galacturonate to a sufficient level for saprophytic growth. But, when inducing plant molecules are present, Pel synthesis is strongly induced to a higher level appropriate to rotting plant tissues quickly.

Preliminary characterization experiments indicate that the plant extract contains at least one compound responsible for the inducing effect on Pel synthesis. Total purification and subsequent characterization of active molecules have not been successful because of precipitation of the inducing compound. However. preliminary characterization revealed that the inducing factor is thermoresistant, has a small molecular mass and is neither a phenolic nor a flavonoid compound.

Agrobacterium tumefaciens and E. chrysanthemi are both well-studied Gram-negative phytopathogenic bacteria which attack wounded plants. We can establish a parallel between induction mechanisms for virulence genes in each bacterium. Specific monosaccharides and particular phenolic compounds play a synergistic role in vir gene induction in $A$. tumefaciens (Cangelosi et al., 1990; Shimoda et al., 1990; Winans, 1991). Likewise. we demonstrated that in E. chrysanthemi monosaccharides, KDG and DKII, with unidentified plant molecules also play a synergistic role in pectate lyase induction. In Agrobacterium, the VirA protein serves as an environmental sensor to detect the plant signal molecules and transduces this signal to the VirG protein that activates vir gene expression (Winans, 1991). It would be interesting to determine if a protein equivalent to the $\operatorname{vir} A$ product exists in Erwinia to serve as a plant signal molecule receptor.

We are grateful to Nicole Hugouvieux-Cotte-Pattat and Hélène Dominguez for providing pelB, pelC, pelD and pelE : : uidA fusions, and to Nicolas Bardonnet for providing uidA (kan) cassettes before publication. We thank Yvan Rahbé for his help during purification of plant molecules and Guy Condemine for his helpful discussions during this work. The work was supported by grants from the CNRS, the MRT and the region Rhône-Alpes.

\section{References}

Ausubel, F. M., Brent, R., Kingston, R. E., Moore, D. D., Seidman, J. G., Smith, J. A. \& Struhl, K. (1987). Current Protocols in Molecular Biology. New York: Wiley-Interscience.

BaCHMANN, B. S. (1990). Linkage map of Escherichia coli K12. Edition 8. Microbiological Reviews 54, 130-197.

Barras, F., Thurn, K. K. \& Chatterjee, A. K. (1987). Resolution of four pectate lyase structural genes of Erwinia chrysanthemi EC 16 and characterization of the enzymes produced in Escherichia coli. Molecular and General Genetics 209, 319-325. 
Bertheau, Y., Madgidi-Hervan, E., Kotoujansky, A., NGuyen-The, C., Andro, T. \& Coleno, A. (1984). Detection of depolymerase isoenzymes after electrophoresis or electrofocusing, or in titration curves. Analytical Biochemistry 139, 383-389.

Boccara, M., Diolez, A., Rouve, M. \& Kotoujansky, A. (1988). The role of individual pectate lyases of Erwinia chrysanthemi strain 3937 in pathogenicity on Saintpaulia plants. Physiological and Molecular Plant Pathology 33, 95-104.

Bolivar, F. (1978). Construction and characterization of new cloning vehicles. III. Derivatives of plasmid pBR322 carrying unique EcoRIgenerated recombinant DNA molecules. Gene 4, 121-136.

Bolton, G. W., Nester, E. W. \& Gordon, M. P. (1986). Plant phenolic compounds induce expression of the Agrobacterium tumefaceins loci needed for virulence. Science 232, 983-985.

Cangelosi, G. A., Ankenbauer, R. G. \& Nester, E. W. (1990). Sugars induce the Agrobacterium virulence genes through a periplasmic binding protein and a transmembrane signal protein. Proceedings of the National Academy of Sciences of the United States of America 87, 6708-6712.

Chatterjee, A. K., Thurn, K. K. \& Tyrel, D. J. (1985). Isolation and characterisation of $\operatorname{Tn} 5$ insertion mutants of Erwinia chrysanthemi that are deficient in polygalacturonate catabolic enzymes oligogalacturonate lyase and 3-deoxy-D-glycero-2,5-hexodiulosonate dehydrogenase. Journal of Bacteriology 162, 708-714.

Collmer, A. \& Bateman, D. F. (1981). Impaired induction and selfcatabolite repression of extracellular pectate lyase in Erwinia chrysanthemi mutants deficient in oligogalacturonide lyase. Proceedings of the National Academy of Sciences of the United States of America 78, 3920-3924.

Collmer, A. \& Keen, N. T. (1986). The role of pectic enzymes in plant pathogenesis. Annual Review of Phytopathology 24, 383-409.

Condemine, G. \& Rober T-Baudouy, J. (1987). Tn 5 insertion in $k d g R$, a regulatory gene of the polygalacturonate pathway in Erwinia chrysanthemi. FEMS Microbiology Letters 42, 39-46

Condemine, G., Hugouvieux-Cotte-Pattat, N. \& Robert-Baudouy, J. (1986). Isolation of Erwinia chrysanthemi $k d u D$ mutants altered in pectin degradation. Journal of Bacteriology 165, 937-941.

DowniE, J. A. \& Johnston, A. W. B. (1988). Nodulation of legumes by Rhizobium. Plant Cell and Environment 11, 403-412.

Favey, S., Bourson, C., Bertheau, Y., Kotoujansky, A. \& Boccara, M. (1992). Purification of the acidic pectate lyase of Erwinia chrysanthemi 3937 and sequence analysis of the corresponding gene. Journal of General Microbilogy 138, 499-508.

Garibaldi, A. \& Bateman, D. F. (1971). Pectine enzymes produced by Erwinia chrysanthemi and their effects on plant tissue. Physiological Plant Pathology 1, 25-40.

Hugouvieux-Cotte-Pattat, N. \& Robert-Baudouy, J. (1985). Lactose catabolism in Erwinia chrysanthemi. Journal of Bacteriology 162, 248-255.

Hugouvieux-Cotte-Pattat, N. \& Robert-Baudouy, J. (1987). Hexuronate catabolism in Erwinia chrysanthemi. Journal of Bacteriology 169, 1223-1231.

Hugouvieux-Cotte-Pattat, N. \& Robert-Baudouy, J. (1989). Isolation of Erwinia chrysanthemi mutants altered in pectinolytic enzyme production. Molecular Microbiology 3, 1587-1597.

Hugouvieux-Cotte-Pattat, N., Reverchon, S., Condemine, G. \& RoBerT-BAUdouY, J. (1986). Regulatory mutation affecting the synthesis of pectate lyases in Erwinia chrysanthemi. Journal of General Microbiology 132, 2099-2106.

Hugouvieux-Cotte-Pattat, N., Reverchon, S. \& Robert-Baudouy, J. (1989). Expanded linkage map of Erwinia chrysanthemi strain 3937. Molecular Microbiology 3, 573-581.

Kotoujansky, A., Diolez, A., Boccara, M., Bertheau, Y., Andro, T. \& COLENO, A. (1985). Molecular cloning of Erwinia chrysanthemi pectinase and cellulase structural genes. EMBO Journal 4, 781-785.

Mantis, N. J. \& Winans, S. C. (1992). The Agrobacterium tumefaciens vir gene transcriptional activator $\operatorname{vir} G$ is transcriptionally induced by acid $\mathrm{pH}$ and other stress stimuli. Journal of Bacteriolegy 174. 1189-1196.

Miller, J. H. (1972). Experiment in Molecular Genetics. Cold Spring Harbor, NY: Cold Spring Harbor Laboratory.

Moran, F., Nasuno, S. \& Starr, M. P. (1968). Extracellular and intracellular polygalacturonic acid transeliminase of Erwinia carotovora. Archives of Biochemistry and Biophysics 123, 298-306.

Novel, G., Didier-Fichet, M. L. \& Stoeber, F. (1974). Inductibility of $\beta$-glucuronidase in wild-type and hexuronate-negative mutants of Escherichia coli K-12. Journal of Bacteriology 120, 89-95.

Perombelon, M. C. M. (1990). Ecology and pathogenicity of soft rot Erwinias: an overview. In Plant Pathogenic Bacteria, pp. 745-751. Edited by Z. Klement. Budapest: Akademiai Kiado.

Redmond, J. W., Batley, M., Djordjevic, M. A., InNes, R. W. KuemPel, P. L. \& Rolfe, B. G. (1986). Flavones induce expression of nodulation genes in Rhizobium. Nature, London 323, 632-635.

Resibois, A., Colet, M., Faelen, M., Schoonejans, E. \& Toussaint, A. (1984). PhiEC2, a new generalised transducing phage of Erwinia chrysanthemi. Virology 137, 102-112.

REVERCHON, S. \& Robert-BAudouy, J. (1987a). Molecular cloning of Erwinia chrysanthemi oligogalacturonate lyase gene involved in pectin degradation. Gene 55, 125-133.

REVERCHON, S. \& RoBerT-Baudouy, J. (1987 b). Regulation of expression of pectate lyase pelA, pelD and pelE in Erwinia chrysanthemi. Journal of Bacteriology 169, 2417-2423.

Reverchon, S., Hugouvieux-Cotte-Pattat, N. \& Robert-Baudouy, J. (1985). Cloning of genes encoding pectolytic enzyme from a genomic library of the phytopathogenic bacteria Erwinia chrisanthemi. Gene 35, 121-130.

Reverchon, S., Van Gijsegem, F., Rouve, M., Kotoujansky, A. \& RoBerT-BAUDOUY, J. (1986). Organisation of a pectate lyase gene family in Erwinia chrysanthemi. Gene 49, 215-224.

Reverchon, S., Hugouvieux-Cotte-Pattat, N., Condemine. G., Bourson, C., Arpin, C. \& Robert-Baudouy, J. (1990). Pectinolysis regulation in Erwinia chrysanthemi. In Plant Pathogenic Bacteria, pp. 739-744. Edited by Z. Klement. Budapest: Akademiai Kiado.

Reverchon, S., Nasser, W. \& Robert-Baudouy, J. (1991). Characterization of $k d g R$, a gene of Erwinia chrysanthemi that regulates pectin degradation. Molecular Microbiology 5, 2203-2216.

ROEDER, D. L. \& Collmer, A. (1985). Marker-exchange mutagenesis of pectate lyase isozyme gene in Erwinia chrysanthemi. Journal of Bacteriology 164, 51-56.

Sambrook, J., Fritsch, E. F. \& Maniatis, T. (1989). Molecular Cloning. A Laboratory Manual. Cold Spring Harbor, NY: Cold Spring Harbor Laboratory.

Shimoda, N., Toyoda-Yamamoto, A., Nagamine, J., Usami. S., Katayama, M., Sakagami, Y. \& Machida, Y. (1990). Control of expression of Agrobacterium vir genes by synergistic action of phenolic signal molecules and monosaccharides. Proceedings of the National Academy of Sciences of the United States of America 87, 6684-6688.

Stachel, S. E., Messen, E., Van Montagu, M. \& Zambryski, P. (1985). Identification of the signal molecules produced by wounded plant cells which activate the T-DNA transfer process in Agrobacterium tumefaciens. Nature, London 318, 624-629.

Stachel, S. E., Nester, E. W. \& Zambryski, P. C. (1986). A plant cell factor induces Agrobacterium tumefaciens vir gene expression. Proceedings of the National Academy of Sciences of the United States of America 83, 379-383.

Tamaki, S. J., Gold, S., Robeson, M., Manulis, S. \& Keen, N. T. (1988). Structure and organisation of the pel genes from Erwinia chrysanthemi EC16. Journal of Bacteriology 170, 3468-3478.

Winans, S. C. (1990). Transcriptional induction of an Agrobacterium regulatory gene at tandem promoters by plant-released phenolic compounds, phosphate starvation, and acidic growth media. Journal of Bacteriology 172, 2433-2438.

WiNans, S. C. (1991). An Agrobacterium two-component regulatory system for the detection of chemicals released from plant wounds. Molecular Microbiology 5, 2345-2350. 